IZA DP No. 6513

Entrepreneurship in Advanced and Developing Countries: A Microeconomic Perspective

Marco Vivarelli

April 2012 


\title{
Entrepreneurship in Advanced and Developing Countries: A Microeconomic Perspective
}

\author{
Marco Vivarelli \\ Università Cattolica del Sacro Cuore, \\ SPRU and IZA
}

Discussion Paper No. 6513

April 2012

IZA

P.O. Box 7240

53072 Bonn

Germany

Phone: +49-228-3894-0

Fax: +49-228-3894-180

E-mail: iza@iza.org

\begin{abstract}
Any opinions expressed here are those of the author(s) and not those of IZA. Research published in this series may include views on policy, but the institute itself takes no institutional policy positions.

The Institute for the Study of Labor (IZA) in Bonn is a local and virtual international research center and a place of communication between science, politics and business. IZA is an independent nonprofit organization supported by Deutsche Post Foundation. The center is associated with the University of Bonn and offers a stimulating research environment through its international network, workshops and conferences, data service, project support, research visits and doctoral program. IZA engages in (i) original and internationally competitive research in all fields of labor economics, (ii) development of policy concepts, and (iii) dissemination of research results and concepts to the interested public.
\end{abstract}

IZA Discussion Papers often represent preliminary work and are circulated to encourage discussion. Citation of such a paper should account for its provisional character. A revised version may be available directly from the author. 


\section{ABSTRACT \\ Entrepreneurship in Advanced and Developing Countries: A Microeconomic Perspective}

The purpose of this paper is to provide a contribution to the identification of the role of entrepreneurship in economic growth by mapping out: 1) alternative ways of looking at entrepreneurship, distinguishing 'creative destruction' from simple 'turbulence'; 2) the different microeconomic determinants of new firm formation, distinguishing 'progressive' from 'regressive' drivers; 3) the relationship between ex-ante characteristics (of the founder) and post-entry performance (of the new firm); and 4) the possible scope for an economic policy aimed at maximizing the impact of entrepreneurship on economic growth. Where possible and appropriate, throughout the paper particular attention is devoted to the specific features characterizing entrepreneurship in developing countries.

JEL Classification: L26, O12

Keywords: entrepreneurship, new firm, innovation, development

Corresponding author:

Marco Vivarelli

Facoltà di Economia

Università Cattolica

Via Emilia Parmense 84

I-29122 Piacenza

Italy

E-mail: marco.vivarelli@unicatt.it 


\section{Introduction}

In recent years a strong belief that 'entrepreneurship' is a crucial driver of economic growth for both developed and developing nations has emerged among both scholars and policy makers (see, for instance Audretsch, Keilbach and Lehmann, 2006 and, for a comprehensive survey, Van Praag and Versloot, 2007). However, moving from macroeconomic scenarios to the micro foundations of entrepreneurship, since the seminal contribution by Baumol (1990) we have known that 'Shumpeterian innovative entrepreneurs' coexist with 'defensive and necessity entrepreneurs', the latter being those who enter a new business not because of market opportunities and innovative ideas, but merely because they need an income to survive. For obvious reasons, this kind of 'survival-driven' self-employment is particularly diffused in the Developing Countries (DCs) (see Naudé, 2009 and 2010), where poverty and lack of formal opportunities in the wage sector often push a large number of people into 'entrepreneurial' activities ranging from street vending to traditional and personal services (in most cases within the informal sector of the economy, see Ihrig and Moe, 2004; Maloney, 2004).

Empirically a world-wide research project, the 'Global Entrepreneurship Monitor' (GEM), has been collecting survey data using standardized definitions and collection procedures on potential and actual entrepreneurship since 1999, and now covers 60 developed and developing countries; see Zacharakis, Bygrave and Shepherd, 2000; Reynolds et al., 2005; Acs, Desai and Klapper, 2008. This project reports the rates of business start-up and of self-employment across different countries of the world, but makes it clear that these

statistics comprise both 'opportunity-motivated' entrepreneurs and those driven by necessity, the latter being defined as those who have started their own firms as a consequence of the following personal situation: "because they cannot find a suitable role in the world of work, creating a new business is their best available option" (Reynolds et al., 2005, p.217).

Within this context, the purpose of this paper is to provide a contribution to the identification of the role of entrepreneurship in economic growth by mapping out: 1) the different microeconomic determinants of new firm formation; 2) the relationship between ex-ante characteristics (of the founder) and post-entry performance (of the new firm); and 
3) the possible scope for economic policy aimed at distinguishing progressive entrepreneurship from defensive and regressive forms of firm formation.

In particular, the macroeconomic and sectoral scenarios remain in the background in this study, being briefly discussed in Section 2, where we attempt to throw some light on the concept of entrepreneurship, extending what has already been mentioned in this Introduction. Section 3 shifts to the core of our analysis, which is microeconomic in nature; factors determining the foundation of a new firm are discussed, distinguishing between 'progressive' and 'regressive' entry drivers. Section 4 is devoted to investigating newborn firms' patterns of learning, survival and growth, and the possible links between ex-ante entrepreneurial features and post-entry performance. Finally, Section 5 briefly discusses some possible policy implications.

Where possible and appropriate, throughout the paper particular attention is devoted to the specific features characterizing entrepreneurship in the low- and middle-income countries, although most of the relevant literature has focused on the richer countries ${ }^{1}$.

\section{What is entrepreneurship?}

According to Schumpeter (1934), entrepreneurship is a driving force of innovation, and more generally an engine for economic development. Indeed, while endogenous growth theorists (see Lucas, 1988; Romer, 1986 and 1990; Grossman and Helpman, 1991; Aghion and Howitt, 1997) highlighted the importance of human capital and R\&D as additional explanations for increasing returns in the aggregate production function, more recently several scholars have proposed entrepreneurship as a third driver of economic growth. According to this hypothesis, entrepreneurs, through their new companies, are able to exploit the opportunities provided by new knowledge and ideas that are not fully

\footnotetext{
${ }^{1}$ Shane (1997) reviewed 472 published articles on entrepreneurship and found that the 13 main authors are all resident in advanced economies and their works deal exclusively with developed countries. More recently, Teixeira (2011), using a bibliometric analysis, has singled out the main authors in the field of entrepreneurship, finding that all of them are based in the developed countries, mainly the US; by the same token, Nyström (2008) has surveyed 37 studies devoted to the analysis of the relationship between entrepreneurship and employment, productivity and economic growth, finding that only 3 of them also considered DCs.
} 
understood and commercialized by the mature incumbent firms (see Acs et al., 2005; Carree and Thurik (2006); Audretsch, Keilbach and Lehmann, 2006; Braunerhjelm et al. 2010). Thus, according to these authors entrepreneurship represents the missing link between investment in new knowledge and economic development, serving as a conduit for both entirely new knowledge and knowledge spillovers (see Carlsson et al., 2009; Audretsch and Keilbach, 2011; for a very recent comprehensive survey based on this view, see Braunerhjelm, 2011).

However, before continuing, the question of what is intended by entrepreneurship and how it can be measured needs to be addressed. In the industrial organization literature the answer is unequivocal: entrepreneurship is the process by which new enterprises are founded and become viable. In this approach, the most common way of measuring entrepreneurship is to look at new firm formation, i.e. at entry rates (either gross or net, that is entry flows minus exit flows). Indeed, according to the OECD (2003), industrial dynamics (i.e. the entry and exit of firms) would account for between 20 and $40 \%$ of total productivity growth in eight selected OECD countries, therefore supporting the idea that entrepreneurs represent one of the driving forces of economic growth and structural change (see Audretsch and Keilbach, 2004; Foster, Haltiwanger and Syverson, 2008; Fritsch, 2011). The reasoning is that new entrants can displace obsolescent firms in a process of ‘creative destruction' (see Schumpeter, 1939 and 1943; for an account in an endogenous growth framework, see Aghion and Howitt, 1992), which may be considered an important micro determinant of productivity dynamics, eventually resulting in economic growth. From such a perspective, entrepreneurs are those individuals Schumpeter labeled “energetic types" who display their "essential features" by introducing the "new" into various activities and by "breaking with the established routines" usually adhered to by managers (see Santarelli, 2006a, p. xii).

In more general terms, it has been argued that new firm formation can be beneficial for economic growth (see Van Stel, Carree and Thurik, 2005), employment generation and unemployment reduction both in developed and developing countries (see Hart and Oulton, 2001; Thurik, 2003; for a recent study assessing the impact of young firms on employment generation and also covering the DCs, see Ayyagari, Demirgüç-Kunt and Maksimovic, 2011). However, recent studies based on GEM evidence have identified a U-shaped 
relationship between a country's rate of entrepreneurial activity and its level of economic development (see Reynolds et al., 2001; Wennekers et al., 2005). Indeed, this evidence that new firm formation is very high in both highly developed and extremely poor countries opens the way to considering entrepreneurship as a multi-faceted concept, not necessarily associated with innovation, productivity growth and economic development. Indeed, only when 'opportunity entrepreneurs' (those motivated by innovative and progressive drivers) are distinguished from 'necessity entrepreneurs' (those who are selfemployed and pushed by defensive and regressive drivers, such as the fear of unemployment), a positive linear relationship between economic development and entrepreneurship is restored (see Carree et al., 2007; Acs, Desai and Hessels, 2008; Acs, $2008)^{2}$. By the same token, when the focus is on DCs, a positive relationship between entrepreneurship and job creation is detectable only when purely self-employment and informal companies are excluded from the analysis (see Ghani, Kerr and O’Connell, 2011a and 2011c).

Turning our attention from the macroeconomic to the sectoral level, the empirical evidence concerning industrial dynamics also casts much doubt on the progressive potentialities of business start-ups. Firstly, survival rates for new firms are strikingly low: according to Bartelsman, Scarpetta and Schivardi (2005), who worked on data for ten OECD countries, about $20-40 \%$ of entering firms fail within the first two years of life, while only 40 to $50 \%$ survive beyond the seventh year (see also OECD, 2003, p. 145). The econometric evidence at the sectoral and microeconomic levels is largely consistent with this outcome; studies on different countries and different sectors reveal that more than $50 \%$ of new firms exit the market within the first five years of activity (see Dunne, Roberts and Samuelson, 1988 and 1989; Reid 1991; Geroski, 1995; Mata, Portugal and Guimaraes, 1995; Audretsch and Mahmood, 1995; Audretsch, Santarelli and Vivarelli, 1999a; Johnson, 2005)³.

\footnotetext{
${ }^{2}$ Recently, Acs and Szerb (2010 and 2012) have put forward a composite "Global Entrepreneurship \& Development Index" where actual and potential individual entrepreneurial characteristics are combined with economic, institutional, cultural and technological variables at the country level; obviously enough, this index turns out to be positively correlated with per capita GDP.

${ }^{3}$ For instance, Audretsch, Santarelli and Vivarelli (1999a) studied 1,570 new Italian manufacturing firms with at least one employee and tracked their post-entry evolution for six years. They found that hazard rates increased markedly during the first two years and then tended to decrease, with a final survival rate after 6 years of activity equal to $59.1 \%$.
} 
Secondly, entry and exit rates are significantly correlated; this is one of the uncontroversial 'stylized facts' of the entry process according to Geroski (1995, p. 424), who pointed out that the "mechanism of displacement, which seems to be the most palpable consequence of entry, affects young, new firms more severely” (see also Baldwin and Gorecki, 1987 and 1991). Indeed, entry and exit rates have been found to be positively correlated across industries in both OECD countries (see Bartelsman, Scarpetta and Schivardi, 2005) and in DCs (see Bartelsman, Haltinwanger and Scarpetta, 2004 ${ }^{4}$ ).

This evidence opens the way to some considerations regarding the alleged role of entry as a vehicle for technological upgrading, productivity growth and employment generation. Consistently, one should be very cautious in seeing entrepreneurship measured as new firm formation as the main driver of development for a DC. If entry were indeed driven mainly by technological opportunities, growing sales and profit expectations, one would observe a negative cross-sectional correlation between entry and exit rates, in particular over short time intervals. On the contrary, entry and exit rates are positively and significantly correlated and market 'churning' emerges as a common feature of industrial dynamics across different sectors and different countries. This means that economic sectors are characterized by a fringe of firms operating at a suboptimal scale where the likelihood of survival is particularly low and where 'revolving door' firms are continuously entering and exiting the market.

Obviously, industry-specific characteristics such as scale economies and the endowment of innovative capabilities (see Audretsch, 1991, and Agarwal and Audretsch, 2001) exert a significant impact on entry, exit, and the likelihood of survival of newborn firms. For example, in industries characterized by a higher minimum efficient scale (MES), small newborn firms face higher costs, which are likely to push them out of the market within a short period after start-up (see Lotti and Santarelli, 2004). Therefore, in many sectors new firm start-ups may simply originate what has correctly been called 'turbulence' (a term first introduced by Beesley and Hamilton, 1984; see also Caves, 1998; Baptista and Karaöz, 2011).

\footnotetext{
${ }^{4}$ The authors used a sample of 22 countries (14 European, 6 Latin American, one each in the US and Canada) and found that the correlation between entry and exit rates across industries in 1990 was positive and significant in the vast majority of cases (Bartelsman, Haltinwanger and Scarpetta, 2004, p.21, Table 6).
} 
By the same token, new firm formation may be more or less conducive to technological upgrading and industry growth, according to the different sectors in which it occurs. For instance, 'new technology-based firms' (NTBFs; see Acs and Audretsch, 1990; Colombo, Delmastro and Grilli, 2004) in advanced manufacturing and ICT services certainly play a different role compared with small-sized start-ups in traditional sectors ${ }^{5}$. Therefore, in some sectors the 'creative destruction' role of new firm formation may be dominant compared with simple 'turbulence', while the opposite may hold in other sectors.

These considerations concerning the role of the industrial structure are particularly relevant for the DCs, where the dominant role of traditional and low-tech sectors renders turbulence more likely and the presence of progressive/innovative entrepreneurs an exception. Indeed, Schumpeter himself (1912 and 1939) makes it clear that the entry of new firms is due to a vast majority of imitators and a tiny minority of leaders (innovators). According to Baumol (2005), 'replicative’ entrepreneurs are those who start a firm similar to alreadyexisting businesses; indeed, when considering gross entry across all economic sectors, we encounter a huge multitude of replicators and very few innovative entrepreneurs (innovators). This is explicitly recognized and discussed by Baumol (2010), who states that "...in reality, the vast majority of all entrepreneurs appear to be of the replicative variety” (ibidem, p.18). Moreover, even among the innovative entrepreneurs, radical innovations are very rare: "Casual empiricism indicates that the bulk of the novelties such entrepreneurs introduce are only slightly better 'mousetraps'” (ibidem, p. 50). In contrast with the 'apologia' which tends to identify entrepreneurship with innovation, Baumol correctly points out that innovative entrepreneurs are the exceptions (the so-called 'superstars', see Baumol, Schilling and Wolff, 2009), while most new firm founders belong to what Schumpeter called the "cluster of followers".

These considerations at the macroeconomic and sectoral levels imply that it will be extremely interesting to look at the microeconomic variety characterizing new entrants ${ }^{6}$. In fact, as in many other fields of economics, 'heterogeneity' (see Dosi, 1988; Dosi et al., 1995) is a crucial feature in explaining the start-up of new firms, the variability in their chances of survival, their different post-entry performances and therefore their extremely

\footnotetext{
${ }^{5}$ However, even in the innovative sectors the degree of uncertainty inherent in new knowledge dictates that only those new firms that prove to be viable grow rapidly, while other attempts that turn out not to be viable stagnate and may ultimately imply exit from the market (see Audretsch and Thurik, 2000).
} 
diverse potential to affect productivity growth and economic development. The next section is devoted to developing this microeconomic perspective, with the aim of investigating the individual characteristics of newborn firm founders and discussing the related empirical evidence.

\section{The microeconomic drivers of entrepreneurship}

In this section we attempt to give an account of the different drivers of entrepreneurship, moving from the microeconomic context (Section 3.1), to the individual/personal characteristics of the entrepreneurial agents (Section 3.2).

\subsection{Progressive vs regressive determinants of entry}

In the textbook view originally put forward by Mansfield (1962), a queue of well-informed potential entrepreneurs is supposed to be waiting outside the market, and the expected level of profit is considered the trigger factor determining entry (see also Orr, 1974; Khemani and Shapiro, 1986). However, according to more recent studies in this stream of literature, new firm formation may be triggered not only by profit expectations, but also by other pull factors such as economic growth and high innovative potential (see see Acs and Audretsch, 1989a and 1989b; Geroski, 1995).

Moreover, again according to a conventional industrial organization (IO) textbook approach, entry can be hindered on the one hand by exogenous entry barriers such as the amount of the initial investment to proxy the MES (see Geroski and Schwalbach, 1991) or the presence of bureaucratic entry regulations (see Djankov et al., 2002; Klapper, Laeven and Rajan, 2006), and on the other hand by endogenous entry barriers such as R\&D and advertising expenditures (see Sutton, 1991; Arauzo-Carod and Segarra-Blasco, 2005).

\footnotetext{
${ }^{6}$ See also Santarelli and Vivarelli (2002 and 2007); Vivarelli (2007), Chap. 1.
} 
However, the main limitation of the IO approach is that it focuses on market mechanisms and may obscure the decision-making process at the level of the individual ${ }^{7}$ (see Winter, 1991), thus underestimating the factors behind the entrepreneur's motivation in starting a new business. Indeed, some $20^{\text {th }}$ century authors such as Knight (1921), Schumpeter (1934 and 1939) and Oxenfeldt (1943) drew attention to the characteristics of the founder of a new firm. Following their contributions, we are aware that important individual determinants may act as push factors and be related both to environmental circumstances and to the potential founder's personal characteristics.

For instance, the specific local/sectoral labor market plays an important role given that the vast majority of new founders, approx. 2/3 of them, were previously employed/located in the same geographical area and the same sector, the rest being young people in their first job experience, or ex-entrepreneurs and founders moving in from an outside region (see Vivarelli, 1991; Storey, 1994; Cressy, 1996; Arrighetti and Vivarelli, 1999; Shane, 2000; Klepper, 2001; Helfat and Lieberman, 2002; Stam, 2007). Individuals starting a new firm in the same sector and the same region as they were previously employed/located in are more likely to be characterized by a deeper understanding of firm organization in that specific sector and of the inner and 'relational' features of the business environment in which the new firm will operate (Storey, 1994) ${ }^{8}$. Therefore, entrepreneurship is strongly characterized by sectoral and locational inertia, thus turning out as a phenomenon affected by a significant persistence (see Fritsch and Mueller, 2007) ${ }^{9}$.

Within this framework, new firm formation can be modeled as an income choice based on a comparison between the wage earned in the previous job and the expected profit as an entrepreneur starting a new business in the same sector and in the same geographical area (see Creedy and Johnson, 1983; Vivarelli, 1991; Foti and Vivarelli, 1994; Audretsch, 1995; Geroski, 1995; Reynolds, 1997; Vivarelli, 2004; for the DCs, see Lévesque and Shepherd, 2004). Contrary to the textbook approach, in self-employment theory the foundation of a

\footnotetext{
${ }^{7}$ In the conventional approach, entrepreneurship is generally measured as the number of new firms relative to the size of the existing population of businesses in a given industry (see Acs, 2006). In contrast, if the individual 'push factors' are taken into account fully, new firms have to be related to the labour force (for further discussion, see Santarelli, Carree and Verheul, 2006; Vivarelli, 2007).

${ }^{8}$ Indeed, what the founder of a new firm knows and can do is related to what (s)he learned in the organization by which (s)he was formerly employed (Cooper 1985; Colombo and Grilli, 2005).

${ }^{9}$ Investigating the link between entrepreneurship and economic geography is beyond the scope of the present work; for a recent and detailed survey on this subject, see Frenken, Cefis and Stam (2011).
} 
new firm is therefore not fostered by absolute profitability, but by the difference between expected profits and current local wages in the same sector, taking into account the surrounding environmental conditions and the risk differential between the two occupational alternatives (Kihlstrom and Laffont, 1979; Parker, 1997; Grilo and Thurik, 2006, Cressy, 2006, Klepper, 2009). This means that entry may have a counter-cyclical component and may well be induced by industrial restructuring and decreasing real wages rather than by buoyant demand expectations and an appropriate endowment of entrepreneurial capabilities (see Highfield and Smiley, 1987; Hamilton, 1989) ${ }^{10}$.

Pushing this argument further, founding a new firm may be an alternative to uncertain future career prospects, or even represents an 'escape from unemployment' (see Oxenfeldt, 1943; Evans and Leighton, 1990; Storey, 1991 and 1994). The empirical evidence suggesting the important role of job losses in fostering entry is indeed quite robust (see Storey and Jones, 1987; Santarelli, Carree and Verheul, 2006). Using a panel of Italian data, Audretsch and Vivarelli (1995 and 1996a) found that job losses represent an important 'push factor' in spurring new firm formation at the regional level (together with other factors such as the local industrial structure and the presence of agglomeration and external economies). At the end of the '90s, in the UK the incidence of people starting a firm not because of a market opportunity but just because they had no better choice was about 22\% (see Small Business Service, 2001, p.6). Likewise, unemployment has been found to be one of the most important determinants of 'latent' entrepreneurship in the stagnating Japanese economy of the second half of the '90s (see Masuda, 2006) ${ }^{11}$.

Thus entry may be determined by a set of different environmental factors including some 'progressive' determinants such as profitability and promising technological opportunities, but also 'regressive' determinants such as low wages and the actual condition of being (or the fear of becoming) unemployed. In determining new firm formation, these

\footnotetext{
${ }^{10}$ For instance, Foti and Vivarelli (1994) found confirmation of the 'self employment' model, showing that entry rates are significantly correlated with the income gap between expected profits and current wages in Italian local labor markets.

${ }^{11}$ In a series of my previous studies using different Italian datasets (Vivarelli and Audretsch, 1998; Arrighetti and Vivarelli, 1999; Vivarelli, 2004), the state of actual unemployment or an impending state of unemployment were never found to be a top crucial motivation in determining the decision to start a new business. However, although rather low in the average rankings, the motivation 'escape from unemployment' emerged as being quite important in about $15-20 \%$ of the examined cases.
} 
environmental drivers interact with the potential entrepreneur's personal traits (see next section).

\subsection{The personal characteristics of the entrepreneur}

New firm founders differ with regard to characteristics such as previous work experience, family tradition, financial status, personal motivation. To start with, the founder of a new firm is heavily influenced by his/her own background, with particular reference to his/her previous job experience; as already discussed in the previous section, on the one hand the importance of previous job experience explains sectoral inertia in entrepreneurship, while on the other the loss of (or the fear of losing) the previous job may trigger the start-up of a new business as an 'escape from unemployment' (see Storey, 1982; Johnson, 1986; Bates, 1990; Reynolds et al., 2001; Vivarelli, 2007).

Among the personal characteristics of the founder, family background is also singled out as a key factor by econometric estimates which explain new firm formation as an act of selfemployment (see Evans and Leighton, 1989; Blanchflower and Oswald, 1998; Hout and Rosen, 2000; Reynolds et al., 2001). For instance, in a recent paper Burke, FitzRoy and Nolan (2008) studied a cohort of British individuals born in March 1958, discovering that self-employed fathers, as well as fathers who are managers of small firms, tend to encourage entrepreneurship among their sons and daughters.

Another important stream of literature has investigated the impact of financial constraints on business start-ups, mostly following on from the work by Fazzari, Hubbard and Petersen (1988). For instance, Evans and Jovanovic (1989) found that the initial level of assets strongly influences the probability of self-employment (see also Blanchflower and Osvald, 1998; Cabral and Mata, 2003; Hurst and Lusardi, 2004; Kan and Tsai, 2006). Other studies have examined the probability of transition to self-employment after an unexpected financial gain, such as a lottery prize, a windfall gain or a job bonus. Interestingly, these studies almost invariably found that the exogenous arrival of new financial resources increases the probability of starting up a company (see Holtz-Eakin, Joulfaian and Rosen, 1994; Lindh and Ohlsson, 1996). The fact that wealth, inheritance 
and windfall gains spur entrepreneurship suggests that business start-ups are often underfinanced (see Parker, 2004). Therefore, since most new companies need external capital, differences in the ability of capital markets to select and finance the most promising entrepreneurial projects may lead to important differences in the level and quality of entrepreneurship across countries, with DCs obviously suffering a disadvantage in this respect (see Kerr and Nanda, 2011; for an extensive discussion, see below: Sections 4.1 and 4.2.2).

Other studies show that non-economic personal factors may turn out to be even more important than environmental variables such as profit expectations, entry barriers, conditions of the local labour and capital markets. For instance, the potential entrepreneur seems to be strongly influenced by specific psychological attitudes, such as a desire to be independent, a search for autonomy in the workplace, an aspiration to full exploitation of previous job experience and acquired ability, a desire to be socially useful and to acquire improved social status (see Creedy and Johnson, 1983; Evans and Leighton, 1990; Blanchflower and Meyer, 1994; Blanchflower and Osvald, 1998; Vivarelli 1991 and 2004; Zacharakis, Bygrave and Shepherd, 2000) ${ }^{12}$.

Since new firms are founded on the basis of both objective economic pull factors (such as profitability and industry growth) and personal, subjective and non-economic push factors including defensive drivers, one could hypothesize that some of the observed entries are simply due to 'entry mistakes' (see Cabral, 1997; Geroski and Mazzucato, 2001), resulting in early failure, turbulence and churning (see previous section).

While entry mistakes conflict with a conventional approach in which potential entrants are driven by rational expectations based on expected profits ${ }^{13}$, they can be understood more

\footnotetext{
12 Questionnaire analyses conducted by the author (Vivarelli and Audretsch, 1998, p. 492; Arrighetti and Vivarelli, 1999, p. 933; Vivarelli, 2004, p.44) invariably show that a search for independence and a desire to fully exploit his/her own skills are ranked first among the determinants of new firm formation. On the other hand, textbook determinants such as profit expectations and the search for a market niche turn out to be important, but ranked below the personal/psychological motivations. Interestingly enough, innovation always lags behind, with a minority of firms (about $15-20 \%$ ) indicating the desire to introduce product and/or process innovation as a fundamental reason for starting a new independent economic activity.

${ }^{13}$ However, some theoretical models of entry such as those proposed by Jovanovic (1982) and Hopenhayn (1992) managed to combine maximising behaviour with the occurrence of 'entry mistakes' which can later be detected by rational learning processes (see Section 4.1 below). On the contrary, entry mistakes are not easily conceivable within the 'Austrian' approach (see Kirzner, 1973 and 1995) where profit opportunities are not likely to be recognized by all the potential entrepreneurs, but only by the 'alerted' ones which are able to recognise latent, overlooked opportunities.
} 
easily by taking into account the fact that potential entrepreneurs may well be affected by overconfidence, generating excess of entry, which in turn leads to infant mortality and entrepreneurial disillusion (see Dosi and Lovallo, 1998; for an experimental economics exercise see Camerer and Lovallo, 1999). Parker (2006) discusses both the psychology literature that gives reasons for expecting entrepreneurs to be especially prone to unrealistic over-optimism, and previous empirical evidence showing that optimism is significantly and positively associated with the propensity to be an entrepreneur (see De Meza, 2002; Åstebro, 2003; Coelho, de Meza and Reyniers, 2004).

If one takes into account the (often dominant) psychological attitudes discussed above (especially a desire to be independent, a desperate search for autonomy caused by frustration in the previous job, a fear of becoming unemployed), entry mistakes and excess entry can be further justified. In fact, the observed occurrence of these entry mistakes suggests an attitude which can be defined as a 'try and see' bet. In this view, new founders, mainly driven by a personal search for autonomy and job satisfaction, 'visit' a sectoral niche searching for business chances; later, they find out whether their entry decision was right or wrong and may decide to exit. Accordingly, market churning, turbulence and early failure, observed at a more aggregate level of analysis, see Section 2, emerge as normal and expected features of industrial dynamics.

These findings lead to the conclusion that several heterogeneous entry processes are simultaneously at play in the economy and that 'opportunity entrepreneurs', those bringing about innovation and economic growth, should be distinguished from 'revolving door' start-ups doomed to early failure and generating only precarious and temporary jobs.

Obviously enough, this distinction is a fortiori crucial when we focus on the DCs, where 'entrepreneurship' and 'self-employment' often generate informal and very transient activities not so very different from 'disguised unemployment'. In the following section an attempt will be made to correlate entrepreneurial characteristics with new firms' actual potentials in terms of economic growth and job creation; special attention will be devoted to evidence from the DCs, when available. 


\section{The post-entry performances of entrepreneurial firms}

Since entrepreneurs are driven by both progressive and regressive determinants and are intrinsically heterogeneous, the post-entry performance of newborn firms and their eventual contribution to economic development may be very diverse as well. In what follows, after a theoretical discussion dealing with the macroeconomic constraints to new firms' growth (Section 4.1), we survey those empirical microeconomic studies which have shown how different 'genetic' characteristics may affect the post-entry performance of newborn firms (Section 4.2).

\subsection{Entrepreneurial learning, market failures and institutional}

\section{constraints}

From a theoretical point of view, Lucas (1978) was the first to put forward a theory of the size distribution of firms based on the relative endowment of entrepreneurial talents ${ }^{14}$. However, the first author to represent the post-entry evolution of newborn firms formally was Boyan Jovanovic in his celebrated contribution in Econometrica (1982). Jovanovic proposed a Bayesian model of noisy selection, according to which efficient firms grow and survive, whereas inefficient ones decline and fail. In particular, in Jovanovic's model of passive learning, firms are initially endowed with unknown, time-invariant characteristics (i.e. ex-ante efficiency parameters); ex-post the prior distribution is updated as evidence comes in and some entrepreneurs discover that they are more efficient than others. Thus, in any period each firm has to decide its strategy: whether to exit, continue at the same size, grow in size, or reduce its productive capacity.

One can easily see that Jovanovic's model is perfectly consistent with a world where founders are quite heterogeneous in terms of both general and specific characteristics,

\footnotetext{
${ }^{14}$ For a recent extension of Lucas' model incorporating the possibility that entrepreneurial talents may be acquired by watching other entrepreneurs already active in the market, see Guiso and Schivardi (2005).
} 
entry mistakes can easily occur, entry can be originated by a 'try and see' bet and early failures are rather common (see previous section; see also Lotti and Santarelli, 2004). The same line of argument applies to more recent models of active learning. While Hopenhayn (1992) first introduced innovation as an exogenous process, Ericson and Pakes (1995) assumed that all the decisions taken by firms were meant to maximize the expected discounted value of the future net cash flow, conditional on the current information set. In their model, a firm knows its own characteristics and those of its competitors, along with the future distribution of industry structure, conditional on the current structure. Therefore, Jovanovic's assumptions concerning small industry size and product homogeneity are relaxed in Ericson and Pakes' model, in which new entries may either adjust in size to the MES level of the 'core' of the industry or choose/find a niche within which the likelihood of survival is relatively high even though the firm does not grow fast. In a subsequent work, Pakes and Ericson (1998) examined two cohorts of firms from Wisconsin in the retail and the manufacturing industries, and found that the structure of the former industry was compatible with Jovanovic's passive learning model, while that of the latter was compatible with their model of active exploration. In both models optimal behavior generates a set of 'stopping states' which can imply early exit from the market.

Characterized by either passive or active learning, founders in these theoretical models are heterogeneous as far as their capabilities and beliefs are concerned, and committed to recursive decisions with early exit always being an available and rational option. In fact, because of either entry mistakes or learning failures, newborn firms may cease in the early phases of their life cycles.

However, in addition to the subjective learning process, the growth of a newborn firm is affected by a larger set of objective variables which have to do with the general macroeconomic and sectoral business climate and with a wide range of constraining factors (see Acs and Audretsch, 1990; Geroski and Schwalbach J., 1991; Audretsch, 1995). With reference to the latter, DCs are characterized by several market failures which severely hamper the post-entry growth potentialities of entrepreneurial activities. As extensively discussed in Biggs and Srivastava (1996), Tybout (2000) and Aterido, Hallward-Driemeier and Pagés, (2009), imperfections in the credit and financial markets, a non-transparent regulatory environment, the lack of infrastructures and the high incidence of bribing are 
important hindering factors affecting firm's growth in DCs. Although the institutional constraints to entrepreneurship are not the core issue of this paper, it is worth discussing them in some detail in the context of DCs, where the entry of new firms faces additional environmental challenges in comparison with what occurs in the more advanced economies.

Starting with capital markets, Rajan and Zingales (1998) and Beck et al. (2008) clearly show that firms in financially dependent industries grow much faster in financially developed countries; in contrast, new small firms in DCs are credit and equity rationed in the vast majority of cases because their financial markets are underdeveloped (see Nugent and Nabli, 1992; Ayyagari, Demirgüç-Kunt, and Maksimovic, 2008 and Section 4.2.2 below). In fact, capital markets in DCs are characterized by: 1) a lower depth (measured, for instance, by a low ratio of bank deposits to GDP; see Paravisini, 2008, for the case of Argentina; Banerjee and Duflo, 2004, for the case of India); 2) by a lower level of competition between financial intermediaries generating misallocation of funds (see Banerjee, Duflo and Munshi, 2003, studying misallocation of capital in India; Cole, 2009, discussing agricultural credit in India); 3) by higher information asymmetries due to institutional and infrastructural underdevelopment (see Klapper and Love, 2011, for a general discussion, while Canales and Nanda (2008) discuss lending to small businesses in Mexico).

By the same token, a non-transparent regulatory environment with regard to labor market rules, taxation, red tape procedures, property rights and bankruptcy laws, is particularly harmful to firms' growth in DCs and may be fatal for young entrepreneurial activities (see Goedhuys and Sleuwaegen 1999; Sleuwaegen and Goedhuys, 2002; Beck, Demirgüç-Kunt and Maksimovic, 2005; Lee et al., 2011). For instance, in a recent study Ardagna, S. and Lusardi, A.M. (2010), dealing with GEM microdata from 37 countries including 8 DCs, showed that stringent entry regulation, soft contract enforcement rules and labor market rigidities play an important role in hindering entrepreneurship and in strengthening the adverse impact of risk aversion.

Moreover, apart from the legal and institutional drawbacks characterising a developing country, a prominent role is also played by the wide diffusion of bribing, which may abort 
any chance of growth of a fragile new entrepreneurial activity ${ }^{15}$. For instance, Fisman, and Svensson (2007), using data collected from 126 Ugandan firms, show that a 1\% increase in the bribery rate implies a reduction of $3 \%$ in firm sales growth. Obviously, corruption may amplify the hampering role of credit constraints (see above) when it involves bank officials responsible for screening the entrepreneurial initiatives (see Beck, Demirgüç-Kunt and Maksimovic, 2005).

Finally, the lack of an adequate infrastructural endowment including roads and railways, basic utilities such as electricity and water supply, and ICT networks, is singled out by the literature as a significant shortcoming in preventing young and small firms in DCs from growing (see Aterido, Hallward-Driemeier and Pagés, 2009; Goedhuys and Sleuwaegen, 2010 ${ }^{16}$; Ghani, Kerr, and O’Connell, 2011b).

Therefore market failures, the infrastructure endowment and regulatory and legal conditions are important determinants of the post-entry performance of newborn firms in DCs. However, the focus of this study is rather on those microeconomic and personal characteristics that coeteris paribus may have a role in determining the post-entry performance of entrepreneurial new firms; the following section discusses this issue.

\subsection{Empirical microeconomic studies}

From an empirical perspective, a relatively recent stream of literature has focused on the post-entry performance of firms and has investigated the survival, growth and early exit of newborn firms (among the early studies, see, for instance: Reid, 1991; Boeri and Cramer, 1992; Baldwin and Rafiquzzaman, 1995). Within this field of research, it is possible to analyze the relationship between the ex-ante features of entry on the one hand, and both survival and, conditional on survival, the post-entry performance of newborn firms on the other. The following subsections are devoted to investigating what have been found to be

\footnotetext{
15 Aterido, Hallward-Driemeier and Pagés (2009, p.10), using evidence from the World Bank Enterprise Surveys, show that $42 \%$ of firms declare they have paid bribes, with an average amount paid of $1.5 \%$ of sales.

${ }^{16}$ The authors, using data from the World Bank Investment Climate Survey covering 947 manufacturing SMEs in 11 Sub-Saharan countries, show that firms with their own transport facilities and their own website exhibit higher growth rates, measured in terms of employment creation.
} 
the most important 'genetic' characteristics affecting the post-entry performance of new businesses.

\subsubsection{Firm's size and age}

Many studies have discovered a positive relationship between start-up size and survival (see Audretsch and Mahmood, 1995; Mata, Portugal and Guimaraes, 1995; Agarval and Audretsch, 2001; for more controversial results, see Audretsch, Santarelli and Vivarelli, 1999a and 1999b). Since entry implies sunk costs (see Sutton, 1991) and generally occurs at a scale that is lower than the MES, a larger entry size is a signal of commitment and self confidence and makes both the occurrence of an entry mistake (see Section 3.2) and the risk of a failure due to diseconomies of scale less likely.

On the other hand, a vast number of papers have found (conditional on survival), a negative relationship between start-up size and post-entry growth, thus rejecting Gibrat's Law (see Gibrat, 1931; Hall, 1987; Hart and Oulton, 1996; Sutton, 1997; Goddard, Wilson and Blandon, 2002; Bottazzi and Secchi, 2006; Lotti, Santarelli and Vivarelli, 2003 and 2009). This evidence means that smaller entrants with a sub-optimal entry size and with a higher risk of early failure (see above) must grow in order to survive and reach the MES as soon as possible.

Consistently, a firm's age turns out to be positively correlated with survival and negatively with growth (see Evans, 1987; Dunne and Hughes, 1994; Yasuda, 2005; Calvo 2006). This is not surprising and is consistent with the learning theories discussed in the previous Section 4.1: experienced, mature firms are more able to deal with market dynamics and so more likely to survive; however, having already reached (or being very close to) the MES, they do not have to grow very fast.

While all the studies cited so far concern developed countries, the evidence from DCs is similar. For instance, Das (1995), dealing with the Indian computer industry, found a significant negative relationship between firm growth and initial firm size; McPherson (1996), in a study on five southern African countries, detected a significant negative link between firm growth and both the firm's size and age; Goedhuys and Sleuwaegen (2000) 
and Sleuwaegen, L. and Goedhuys, M. (2002), respectively analyzing 141 and 129 manufacturing firms in Côte d'Ivoire, also found negative correlations between firm growth and both firm size and age; finally, running GMM-SYS panel estimates covering census-based Ethiopian manufacturing firms over the period 1996-2003, Bigsten and Gebreeyesus (2007) showed how the negative relationship between size and age on the one hand and firms' employment growth on the other is significant and robust to sample selection and unobserved firm heterogeneity ${ }^{17}$.

\subsubsection{Credit rationing}

Credit constraints and lack of financial capital in general should limit the rate of entry of new businesses, and their likelihood of survival and rate of growth (see $\mathrm{Xu}, 1998$; Carpenter and Petersen, 2002; Becchetti and Trovato, 2002; Aghion, Fally and Scarpetta, 2007). However, some recent studies have shown that the role of credit rationing has been somewhat over-emphasized and that entrepreneurial saving plans may be able to overcome borrowing constraints (Cressy, 1996 and 2000; Parker, 2000; Hurst and Lusardi, 2004). The risk of overstating the hindering role of credit constraints is particularly high in questionnaire analyses where nascent or newborn entrepreneurs are asked to list their main difficulties in starting and/or running a new firm; in fact, they have the self-indulgent tendency to indicate a lack of external financial support as the main cause of their problems, while in most cases this is just a symptom of more fundamental deficiencies internal to the firm.

At any rate, as already discussed in Section 4.1, new entrepreneurial initiatives in the DCs are credit-rationed in the vast majority of cases due to lack of collateral, informational asymmetries and largely imperfect local capital markets. For instance, Goedhuys and Sleuwaegen (2010), in a study investigating 947 small and medium entrepreneurial firms in several manufacturing firms in eleven Sub-Saharan African countries ${ }^{18}$, report that financial constraints are singled out as the major obstacle (from between eleven

\footnotetext{
${ }^{17}$ Consistent econometric outcomes can also be found in Mead and Liedholm (1998); Gunning and Mengistae (2001); Bigsten and Söderbom (2006).

${ }^{18}$ The authors extracted their firm-level data from the World Bank Investment Climate Survey.
} 
alternatives) to a firm's growth in 5 countries out of 11 . Consistently, in the previouslycited paper on Côte d'Ivoire by Goedhuys and Sleuwaegen (2000), the authors find that a lack of collateral significantly hampers firms' growth (ibidem, p.139). In this framework, the successful diffusion of microfinance in DCs can be seen as a way of reducing information and transaction costs in screening and financing small and new businesses (see Yunus, M., 1999 and 2002; Fogel, Lee and McCumber, 2011).

\subsubsection{Education}

Not surprisingly, it has been demonstrated that education and human capital have an important role in increasing the likelihood of survival of new firms and in improving their post-entry economic performance (see Bates, 1990; Gimeno et al., 1997; Acs, Armington and Zhang, 2007). In particular, human capital aspects turn out to be particularly important in fostering entrepreneurship in the high-tech sectors; for instance, Baptista and Mendonça (2010) show that local access to knowledge and human capital significantly affect entry by knowledge-based firms, while Colombo and Grilli (2010) point out that the founder's human capital is a key driver of post-entry growth of high-tech start-ups.

However, while the role of human capital in improving the post-entry performance of new firms is recognized, the issue of whether specific rather that general human capital (Becker, 1964) is the crucial asset, is more controversial. Some authors have found that specific rather than generic skills are better predictors of improved post-entry performance, especially as far as NTBFs are concerned (see Almus and Nerlinger, 1999; Colombo and Grilli, 2005). In this context, specificity refers to education in economic/managerial and technical/scientific fields and to previous work experience in technical and commercial functions within the same industry.

However, Lazear (2004 and 2005) theorized that an individual who is well endowed in a variety of fields, a 'Jack-of-all trades', would have a higher probability of becoming an entrepreneur, since entrepreneurs have to manage different people and tasks and so have to be well-versed in a variety of abilities. As a consequence, this theory also predicts that nascent entrepreneurs should plan a human capital investment strategy which is well- 
balanced across different competences and fields of expertise. Using cross section analyses, both Lazear (2005) and Wagner (2003) found that students who ended up as entrepreneurs had studied a much more varied curriculum than those who ended up working for others. Overall, these researchers conclude that accumulation of a balanced skill-mix (i.e. general human capital) causally involves entrepreneurship and aboveaverage post-entry performance (in contrast with the positive role of specific human capital discussed above) $)^{19}$.

Turning our attention to DCs and taking into account that in this context entrepreneurship and self-employment are often carried out within the informal sector of the economy, the impact of education turns out to be controversial. In fact, higher education, either general or specific, augments the managerial capabilities which are necessary to run a business enterprise, but also increase the outside option for salaried employment in the formal sector of the economy. This is probably the reason why Van de Sluis, Van Praag and Vijverberg (2004), in their comprehensive survey of the previous literature focusing on DCs, found that in the majority of cases education lowers the likelihood of entering self-employment as contrasted with wage-earning employment. In contrast, Goedhuys and Sleuwaegen (2000), running logit estimations on data concerning the owners of 141 manufacturing firms in Côte d'Ivoire, found that the probability of being an entrepreneur is strongly stimulated by both apprenticeship and formal education, with the positive effect of education steadily increasing going from lower to higher levels of education. Similarly, Ghani, Kerr, and O’Connell (2011b), using cross-sectional establishment-level surveys of manufacturing and services companies in Indian districts, conclude that higher education in a local area significantly increases the supply of entrepreneurs ${ }^{20}$. However, this relationship becomes non-significant when the informal manufacturing sector is taken into account. This is an interesting outcome and confirms the fact that education may render the

\footnotetext{
${ }^{19}$ Some recent papers cast doubt on this conclusion. In fact, individual unobservable characteristics may indeed simultaneously affect both skill accumulation and occupational choice, i.e. individuals innately wellversed in a variety of fields would have the incentive both to accumulate more balanced skills and to become entrepreneurs. If such is the case, no causal relationship would be detectable between the spread of knowledge across different fields and the choice to become an entrepreneur (see Åstebro, 2005; Silva 2007; Åstebro and Thompson, 2011).

${ }^{20}$ This outcome is consistent with similar evidence recently found for the developed countries, see Doms, Lewis and Robb, 2010; Glaeser, Kerr and Ponzetto, 2010.
} 
choice of being a wage earner as preferable to entering self-employment in the informal sector (often characterized by 'defensive entrepreneurship’, see Sections 2 and $3^{21}$ ).

On the other hand, evidence concerning the relationship between education and the postentry performance of new businesses in DCs is uncontroversial and consistent with what has been found using data from richer countries. For instance, Van de Sluis, Van Praag and Vijverberg (2004) conclude that an additional year of schooling raises entrepreneurial income by an average of 5.5\%; by the same token, McPherson (1996) found that in Botswana and Zimbabwe business owners who have completed secondary school run faster-growing firms than those proprietors with no schooling; finally, Goedhuys and Sleuwaegen (2000 and 2010), using data respectively from Côte d'Ivoire and from eleven Sub-Saharan African countries, found unequivocal evidence that formal education of the entrepreneur positively affect a firm's growth performance, respectively measured in terms of the growth rates of sales and employment (in both studies, the greatest effect on growth is found for entrepreneurs holding a university degree).

\subsubsection{Previous job}

As pointed out in Section 3.1, entrepreneurship is characterized by sectoral and geographical inertia; far from being a disadvantage, persistence in entrepreneurship generates above-the-average post-entry performance, since past experience in the same sector and in the same area is often a signal of better skills and informational advantages. Indeed, in a recent paper, Michelacci and Silva (2007) found that the fraction of entrepreneurs who set up their businesses in the area where they were born was significantly higher than the corresponding share for dependent workers and, more importantly, that firms created by locals were bigger, more valuable, more capital-intensive and better financed than their counterparts created by non-locals. The authors interpreted their findings by arguing that local entrepreneurs can on average better exploit the economic and financial opportunities available in the region where they were born. By the

\footnotetext{
${ }^{21}$ By the same token, Nafziger and Terrell (1996), using evidence from India, found that higher education of the founding entrepreneur reduces firm survival, indicating the importance of outside opportunities in paid
} 
same token, Dahl and Sorenson (2011) found that companies perform better, survive longer and generate higher profits when located in regions in which their founders have lived longer, this effect being similar in size to that associated to previous experience in the same sector.

Following this line of reasoning, both spinoffs (entrepreneurs leaving a mother firm to found a new business) and 'serial entrepreneurs' (founders who have previously run other businesses) may have an advantage compared with "de novo" entrepreneurs. For example, Hirakawa, Muendler and Rauch (2010), using microdata from Brazil over the 1995-2001 period, found that spinoffs are characterized by larger entry sizes (see Section 4.2.1) and lower exit rates than new firms without parents. Similarly, the role of past experience and path-dependence is confirmed by the fact that serial entrepreneurs are more likely to replicate the success of their past companies than single venture entrepreneurs or serial entrepreneurs who failed in their prior business (see Gompers et al., 2006).

Turning our attention to a managerial perspective, new founders who had previously been employed as top managers in the same sector and who had better access to relevant information are expected to exhibit better post-entry business performance (for an empirical validation of these relationships, see Cooper, Gimeno-Gascon and Woo, 1994; Cressy, 1996; Arrighetti and Vivarelli, 1999; Lee and Tsang, 2001; Shane, 2001; Vivarelli, 2004).

Some studies confirm the positive link between previous job experience and a firm's postentry performance in the case of DCs too. For example, McPherson (1996) found a positive relationship between annual employment growth and previous experience of the founder in similar economic activities for entrepreneurial firms in Swaziland and Botswana, while Vijverberg (1991) and Goedhuys and Sleuwaegen (2000), both studying Côte d'Ivoire, found that job experience previously acquired in the same industry both increases the likelihood of founding a new business and contributes to a firm's better performance. 


\section{$\underline{4.2 .5 \text { Innovation }}$}

If the underlying motivation to start a new firm is linked to innovative projects, then a better post-entry performance should be expected. Empirically, this seems to be the case. In fact, a propensity for innovation emerges in general as a firm's growth driver (see, for instance, Freel, 2000 and Coad and Rao, 2008) and specifically as a positive predictor of survival and an above-the-average post-entry performance of newborn firms (see EstevePèrez, Sanchis and Sanchis, 2004; Raspe and Van Oort, 2008). For instance, Arrighetti and Vivarelli (1999), after applying a factor analysis to a sample of 147 Italian spinoffs, found that innovative factors ${ }^{22}$ were significantly correlated with post-entry performance; their subsequent cluster analysis also revealed that the innovative group was more likely to have a better post-entry performance (see also Vivarelli and Audretsch, 1998).

Consistently with the discussion above, Cefis and Marsili (2006) found convincing evidence of an 'innovation premium' in survival time: using Pavitt’s (1984) taxonomy, they showed that young firms (less than four years old) in the 'science-based' and 'specialized supplier' sectors were characterized by significantly higher chances of survival than firms in other sectors (ibidem, Fig. 1 and Table 2). More specifically, Cefis and Marsili (2005) also showed that being an innovator enhanced the expected time of survival by $11 \%$ compared with non-innovator counterparts.

Turning our attention to DCs and bearing in mind that in these countries innovation is generally achieved through the importation and adaptation of technologies developed abroad, and that the role of endogenous R\&D and local NTBFs is extremely limited (see Robbins and Gindling, 1999; Robbins, 2003; Lall, 1992 and 2004; Lee and Vivarelli, 2006), it is not surprising that very few studies try to link innovation with entrepreneurship within a DC context. One exception is Santarelli (2011) who studied entrepreneurship in Vietnam using a panel of regional-level data for 61 provinces over the period 2000-2008; among other outcomes, the author found that an innovative climate (proxied by the share of technical/R\&D personnel in the province) significantly and positively affects the regional net entry rate. Moving to post-entry performance, in the previously-cited work by

\footnotetext{
${ }^{22}$ Related both to the innovative motivations of the founder and to his/her previous innovative experience in the mother firm.
} 
Goedhuys and Sleuwaegen (2010), the innovative capability (proxied by a dummy for the introduction of new products) was found to increase a firm's annual employment growth by $2 \%$ on average.

\subsubsection{Escape from unemployment}

As far as unemployment (or the fear of becoming unemployed, see Section 3.1) is concerned, the literature points out two stylized facts: 1) those who have entered self employment from unemployment exit to a higher extent than those who have entered from paid employment (see Carrasco, 1999; Pfeiffer and Reize, 2000); 2) new founders who were formerly unemployed have on average lower economic outcomes and a lower propensity to contribute positively to job creation. For instance, in the previously-cited paper by Arrighetti and Vivarelli (1999), the authors found that defensive motivations such as concern about future career developments and the fear of becoming unemployed were predictors of a below-the-average post-entry evolution (ibidem, p. 936). By the same token, Andersson and Wadensjö, (2007), using a large sample of Swedish-born men who were self-employed in the period 1999-2002 and who were either wage-earners, unemployed or inactive in 1998, showed that those who were previously unemployed systematically had lower incomes compared to those who were previously wage earners; moreover, they also found that income from self-employment declines with the number of days spent in unemployment and that previously-unemployed entrepreneurs are significantly more likely to be ‘solo’ entrepreneurs, i.e. to have no employees.

As regards DCs, the literature is extremely scarce ${ }^{23}$. However, Wang (2006) found convincing evidence that unemployment had fostered start-ups in Taiwan over the period 1986-2001; in contrast, in the previously-cited work by Santarelli (2011), no significant impact of the unemployment rate on new firm formation in Vietnam was found. 


\subsubsection{The role of ethnic minorities}

While most of the empirical literature on entrepreneurship is biased towards evidence from the industrialized countries, a particular driver of new firm formation is instead mainly studied with regard to $\mathrm{DCs}^{24}$ : the role played by ethnic minorities in generating above-theaverage rates of entry and better post-entry performance among newborn firms. The basic hypothesis is that alien minorities may have an entrepreneurial advantage based on their opportunity to exploit their minority community networks to overcome important hindrances to entrepreneurship (see Section 4.1), such as information asymmetries, high transaction costs, credit constraints and difficulties in accessing available inputs and technologies (see Kilby, 1983 and Biggs and Shah, 2006). In addition, from a sociological point of view, an ethnic minority, characterized by common traits such as language, culture and religion, generates trust, social cohesion and emulation, which are all factors that favor entrepreneurial behavior (see Greif, 1993; Hobday, 1995; Iyer and Schoar, 2010). Finally, a minority group may also be affected by a feeling of insecurity and frustration (in comparison with a dominant group), which encourages members to seek economic success and a better social status (see Elkan, 1988).

Empirical evidence is generally consistent with the hypotheses just discussed; for instance, Ramachandran and Shah (1999) - using firm level data from Kenya, Tanzania, Zambia and Zimbabwe and after controlling for firm size and age, various personal characteristics of the entrepreneurs, as well as sector and country differences - found that Asian and European firms start larger and grow faster than indigenously-owned African firms. By the same token, Hewitt and Wield (1997) show that Asian businesses in the Tanzanian manufacturing sector have a better access to sources of technology than indigenous companies. Consistently, in the previously-cited study by Goedhuys and Sleuwaegen (2000), the dummy variable 'non-African' significantly and positively affects the likelihood of becoming an entrepreneur in Côte d'Ivoire. Similarly, when analyzing a

\footnotetext{
${ }^{23}$ This is a pity since, as discussed in the introduction, 'defensive and necessity entrepreneurs' appear to make up the bulk of self-employment in DCs, with activities ranging from street vending and small retailing to traditional personal services.

${ }^{24}$ One exception are the studies showing how in the US black-owned firms show lower survival rates and worse performances than white- or Asian-owned firms (see Fairlie and Robb, 2007; Jarmin and Krizan, 2010).
} 
randomly-selected sample of 296 Ethiopian SMEs, Mengistae (2001) finds that companies owned by the indigenous minority group of the Gurage perform better than average in the country; in particular, new businesses start larger and then grow faster. More recently, Goedhuys and Sleuwaegen (2010; see above) show that the Asian dummy (equal to 1 for entrepreneurs of Lebanese, Indian, Middle Eastern or other Asian origin) turns out to be positive and significant in affecting firms' growth in Sub-Saharan Africa.

\section{Conclusions and policy implications}

'Entrepreneurship' is an extremely complex, and somewhat controversial phenomenon. From a microeconomic point of view, far from being solely the result of the entrepreneurial 'creative destruction' process proposed by Schumpeterian advocates, any set of entrepreneurial ventures can be seen as a rather heterogeneous aggregate where real and innovative entrepreneurs are to be found together with passive followers, overoptimistic gamblers and even escapees from unemployment. From a macroeconomic point of view, progressive new firm formation can generate permanent economic growth, while defensive and regressive start-ups originate only temporary positive effects, and ultimately market turbulence.

Therefore, both scholars and policy makers should bear some important caveats in mind. Firstly, the evidence discussed in this study calls for a more rigorous definition of the terminology adopted, since the generic term 'entrepreneur' may include a population of very heterogeneous agents. Adopting a provocative stance, one could eliminate the word 'entrepreneur' and substitute it with the term 'founder', which is more general and free from overoptimistic implications.

Secondly, since founders are heterogeneous and may make 'entry mistakes', most new firms are doomed to early failure; this type of entry is not conducive to technological renewal and economic growth, but simply to an excess of entries, market churning and turbulence. In both developed and developing countries, policy makers should discourage this type of venture. 
Thirdly, determinants of entry vary from progressive factors such as demand and profit expectations, innovative potentialities, entrepreneurial human capital built through specific education, family environment and previous job experience, to misleading and regressive factors such as overconfidence, a desire to be independent, a fear of unemployment.

Fourthly, ex-ante 'genetic' features of the founder may be predictors of survival chances and post-entry business performance. For instance, a larger size, the absence of credit constraints, and a larger informational set allowing 'active learning' can be considered as positive predictors of a higher likelihood of survival, while a previous state of unemployment or the absence of an adequate incubator background can be seen as predictors of early failure. By the same token, an endowment of high-level education and human capital, the relevance of the innovative motivation and previous experience in managerial and entrepreneurial roles have been shown to be correlated with above-theaverage post-entry business performance.

Policy makers need to be able to disentangle these drivers and encourage a selected subsample of potential entrepreneurs. In the specific case of DCs, as well as a larger startup size, higher education, longer previous job experience and innovative capabilities, the fact of belonging to an entrepreneurial ethnic minority (see Section 4.2.7) can be seen as an additional preferential trait when deciding how to target a policy addressed at sustaining progressive new firm formation.

In this context, the widespread diffusion of general, 'erga-omnes' entry subsidies as policy instruments in both the developed and the developing countries is unfortunate. More specifically, an 'erga-omnes' entry subsidy may well generate both 'deadweight' and 'substitution' effects. The first occur when the beneficiary of the subsidy is a newborn entrepreneurial firm which would have survived and grown in any case; the second when the incentive supports a revolving door firm which would have exited the market in absence of the subsidy. In the latter case, the distortion is larger, since the subsidy is not only a social waste but also implies the substitution of a potentially more efficient entrant by a subsidized inefficient firm. In fact, in the presence of an incentive, the newborn firm adjusts its own capacity not on the basis of either passive or active learning (see Section 4.1), but as a consequence of the artificial support provided by the received subsidy. Once the subsidy expires, the 'bad entrepreneur' becomes aware of his/her inefficiency and 
leaves the market, cancelling the temporary effect of the policy in terms of economic growth and job creation. If such is the case, public support induces a substitution effect against more efficient potential entrants and delays the exit of less efficient newborn firms. Therefore, 'umbrella' subsidies should be discarded in favor of selective and targeted measures addressed to the more promising potential entrepreneurs, such as those characterized by a superior human capital or by interesting and feasible innovative ideas.

Moreover, subsidies should be conditional on an obvious and unambiguous occurrence of a market failure which prevents otherwise efficient firms from becoming established and growing. This means that in the developed nations, entry subsidies should be allowed only in exceptional situations, when market mechanisms fail to select the better and faster growing enterprises (this could be the case, for instance, of credit-rationed innovative initiatives).

Obviously, the case of DCs is intrinsically different, since market and institutional constraints are much more diffused and severe, ranging from extreme financial rationing to lack of property rights, bribing, etc. (see Section 4.1). However, notwithstanding the particularly adverse conditions faced by potential entrepreneurs in DCs, policy makers in these countries should also direct entry subsidies only at those 'progressive' entrepreneurs proved to be hindered by clearly-detectable market and government failures. 


\section{$\underline{\text { References }}$}

Acs, Z.J. (2006), New Firm Formation and the Region: Empirical Results from the United States, in E. Santarelli (ed.), Entrepreneurship, Growth and Innovation: The Dynamics of Firms and Industries, New York, Springer, 106-133.

Acs, Z.J. (2008), Foundations of High Impact Entrepreneurship, Foundations and Trends in Entrepreneurship, 4, 535-620

Acs Z. J., Armington C. and Zhang T. (2007), The Determinants of New-firm Survival across Regional Economies: The Role of Human Capital Stock and Knowledge Spillover, Papers in Regional Science 86, 367-91.

Acs, Z.J. and Audretsch, D.B. (1989a), Small-firm Entry in US Manufacturing, Economica, 56, 255-65.

Acs, Z.J. and Audretsch, D.B. (1989b), Births and Firm Size, Southern Economic Journal 56, 46775.

Acs, Z.J. and Audretsch D.B. (1990), Innovation and Small Firms, Cambridge (Mass), MIT Press.

Acs, Z.J., Audretsch D.B., Braunerhjelm, P. and Carlsson B. (2005), Growth and Entrepreneurship: An Empirical Assessment, Discussion Papers on Entrepreneurship, Growth and Public Policy, n. 3205, Jena, Max Planck Institute of Economics.

Acs, Z.J., Desai S. and Hessels, J. (2008), Entrepreneurship, Economic Development, and Institutions, Small Business Economics, 31, 219-34.

Acs, Z.J., Desai S., and Klapper, L.F. (2008), What does Entrepreneurship Data Really Show?, Small Business Economics, 31, 265-81.

Acs, Z. J. and Szerb, L. (2010), The Global Entrepreneurship Index (GEINDEX), Foundations and Trends in Entrepreneurship, 5, 341- 435.

Acs, Z. J. and Szerb, L. (2012), Global Entrepreneurship \& Development Index 2012, Cheltenham, Elgar.

Agarval, R. and Audretsch, D.B. (2001), Does Entry Size Matter? The Impact of the Life Cycle and Technology on Firm Survival, Journal of Industrial Economics, 49, 21-43.

Aghion, P. and Howitt, P. (1992), A Model of Growth Through Creative Destruction, Econometrica, 60, 323-51.

Aghion, P. and Howitt, P. (1997), Endogeneous Growth Theory, Cambridge (Mass.), MIT Press.

Aghion, P., Fally. T. and Scarpetta, S. (2007), Credit Constraints as a Barrier to the Entry and Postentry Growth of Firms, Economic Policy, 22, 731-79.

Almus, M. and Nerlinger, E.A. (1999), Growth of New Technology-Based Firms: Which Factors Matter?, Small Business Economics,13, 141-54.

Andersson, P. and Wadensjö, E. (2007), Do the Unemployed Become Successful Entrepreneurs? International Journal of Manpower, 28, 604-26.

Arauzo-Carod, J.M. and Segarra-Blasco, A. (2005), The Determinants of Entry are not Independent of Start-up Size: Some Evidence from Spanish Manufacturing, Review of Industrial Organization, 27, $147-65$. 
Ardagna, S. and Lusardi, A.M. (2010), Explaining International Differences in Entrepreneurship: The Role of Individual Characteristics and Regulatory Constraints, in Lerner, J. and A. Schoar (eds.), International Differences in Entrepreneurship, Chicago, University of Chicago Press, 17-62.

Arrighetti, A. and Vivarelli, M. (1999), The Role of Innovation in the Postentry Performance of New Small Firms: Evidence from Italy, Southern Economic Journal, 65, 927-39.

Åstebro, T. (2003), The Return to Independent Invention: Evidence of Risk-seeking, Extreme Optimism or Skewness Loving?, Economic Journal, 113, 226-39.

Åstebro, T. (2005), Does it Pay To Be a Jack-of-all-trades?, Rotman School of Management, University of Toronto, mimeo, Toronto.

Åstebro, T. and Thompson, P. (2011), Entrepreneurs: Jacks of all Trades or Hobos?, Research Policy, 40, 637-69.

Aterido, R., Hallward-Driemeier, M. and Pagés, C. (2009), Big Constraints to Small Firms' Growth? Business Environment and Employment Growth Across Firms, World Bank Policy Research Working Paper 5032, Washington DC, World Bank.

Audretsch, D.B. (1991), New-Firm Survival and the Technological Regime, Review of Economics and Statistics, 73, 441-50.

Audretsch, D.B. (1995), Innovation and Industry Evolution, Cambridge (Mass), MIT Press.

Audretsch, D.B. and Keilbach, M.C. (2004), Entrepreneurship and Regional Growth: an Evolutionary Interpretation, Journal of Evolutionary Economics, 14, 605-16.

Audretsch, D.B. and Keilbach, M.C. (2011), Knowledge Spillover Entrepreneurship, Innovation and Economic Growth, in Audretsch, D.B., Falck, O., Heblich, S. and Lederer, A. (Eds.), Handbook of Research on Innovation and Entrepreneurship, Cheltenham, Elgar, 245-69..

Audretsch, D.B., Keilbach, M.C. and Lehmann, E.E. (2006), Entrepreneurship and Economic Growth, Oxford, Oxford University Press.

Audretsch, D.B. and Mahmood, T. (1995), New Firm Survival: New Results Using a Hazard Function, Review of Economics and Statistics, 77, 97-103.

Audretsch, D.B., Santarelli, E. and Vivarelli, M. (1999a), Start Up Size and Industrial Dynamics: Some Evidence from Italian Manufacturing, International Journal of Industrial Organization, 17, 965-83.

Audretsch, D.B., Santarelli, E. and Vivarelli, M. (1999b), Does Start Up Size Influence the Likelihood of Survival?, in Audretsch, D. and Thurik, R. (eds.) , Innovation, Industry Evolution and Employment, Cambridge, Cambridge University Press, 280-96.

Audretsch, D.B. and Thurik, A.R. (2000), Capitalism and Democracy in the $21^{\text {st }}$ Century: From the Managed to the Entrepreneurial Economy, Journal of Evolutionary Economics, 10, 17-34.

Audretsch, D.B. and Vivarelli, M. (1995), New Firm Formation in Italy, Economics Letters, 48, 7781.

Audretsch, D.B. and Vivarelli, M. (1996), Determinants of New-Firm Startups in Italy, Empirica 23, 91-105.

Ayyagari, M., Demirgüç-Kunt, A. and Maksimovic, V. (2008), How Important Are Financing Constraints? The Role of Finance in the Business Environment, World Bank Economic Review, 22, 483-516. 
Ayyagari, M., Demirgüç-Kunt, A. and Maksimovic, V. (2011). Small vs. Young Firms Across the World: Contribution to Employment, Job Creation, and Growth, World Bank Policy Research Working Paper 5631, Washington DC, World Bank.

Baldwin, J.R. and Gorecki, P.K. (1987), Plant Creation Versus Plant Acquisition: The Entry Process in Canadian Manufacturing, International Journal of Industrial Organization, 5, 27-41.

Baldwin, J.R. and Gorecki, P.K. (1991), Firm Entry and Exit in the Canadian Manufacturing Sector, Canadian Journal of Economics, 24, 300-23.

Baldwin, J.R., and Rafiquzzaman, M. (1995), Selection Versus Evolutionary Adaptation Learning and Post-entry Performance, International Journal of Industrial Organization, 13, 501-22.

Banerjee, A., Duflo, E. and Munshi, K. (2003), The (Mis)allocation of Capital, Journal of the European Economic Association, 1, 484-94.

Banerjee, A. and Duflo, E., (2004), Do Firms Want to Borrow More? Testing Credit Constraints Using a Directed Lending Program, Banerjee, CEPR Discussion Papers n. 4681, London, CEPR.

Baptista, R. and Karaöz, M. (2011), Turbulence in Growing and Declinig Industries, Small Business Economics, 36, 249-70.

Baptista R. and Mendonça, J. (2010), Proximity to Knowledge Sources and the Location of Knowledge-based Start-ups, Annals of Regional Science, 45, 5-29.

Bartelsman E., Haltiwanger, J. and Scarpetta, S. (2004), Microeconomic Evidence of Creative Destruction in Industrial and Developing Countries, World Bank Policy Research Working Paper 3464, Washington DC, World Bank.

Bartelsman, E., Scarpetta, S. and Schivardi, F. (2005), Comparative Analysis of Firm Demographics and Survival: Evidence from Micro-level Sources in OECD Countries, Industrial and Corporate Change, 14, 365-91.

Bates, T. (1990), Entrepreneur Human Capital Inputs and Small Business Longevity, Review of Economics and Statistics, 72, 551-59.

Baumol, W.J. (2005), Entrepreneurship and Invention: Toward Their Microeconomic Value Theory, AEI-Brookings Joint Center for Regulatory Studies, related publication n.05-38, Washington, Joint Center.

Baumol, W.J (1990), Entrepreneurship: Productive, Unproductive and Destructive, Journal of Political Economy, 98, 893-921.

Baumol, W.J (2010), The Microtheory of Innovative Entrepreneurship, Princeton and Oxford, Princeton University Press.

Baumol, WJ., Schilling M. and Wolff, E. (2009), The Superstars Inventors and Entrepreneurs: How Were They Educated? Journal of Economic and Management Strategy, 18, 711-28.

Becchetti, L. and Trovato, G. (2002), The Determinants of Growth for Small and Medium Sized Firms. The Role of Availability of External Finance, Small Business Economics, 19, 291-306.

Beck, T., Demirgüç-Kunt, A., Laeven, L. and Levine, R. (2008), Finance, Firm Size and Growth, Journal of Money, Credit and Banking, 40, 1379-405.

Beck, T., Demirgüç-Kunt, A. and Maksimovic, V. (2005), Financial and Legal Constraints to Growth: Does Firm Size Matter?, Journal of Finance, 60, 131-77.

Becker, G.S. (1964), Human Capital: A Theoretical and Empirical Analysis, New York, Columbia University Press. 
Beesley, M.E and Hamilton, R.T. (1984), Small Firms' Seedbed Role and the Concept of Turbulence, Journal of Industrial Economics, 33, 217-31.

Biggs, T. and Shah, M.K. (2006), African SMEs, Networks and Manufacturing Performance, Journal of Banking and Finance, 30, 3043-66.

Biggs, T. and Srivastava, P. (1996), Structural Aspects of Manufacturing in Sub-Saharan: Findings from a Seven Country Enterprise Survey, World Bank Discussion Paper 346, Washington DC, World Bank.

Bigsten, A. and Gebreeyesus, M. (2007), The Small, the Young and the Productive: Determinants of Manufacturing Firm Growth in Ethiopia, Economic Development and Cultural Change, 55, 81340.

Bigsten, A. and Söderbom, M. (2006), What Have We Learned from a Decade of Manufacturing Enterprise Surveys in Africa, World Bank Research Observer, 21, 241-65.

Blanchflower, D., and Meyer, B. (1994), A Longitudinal Analysis of Young Entrepreneurs in Australia and the United States, Small Business Economics, 6, 1-20.

Blanchflower, D. and Oswald, A. (1998), What Makes an Entrepreneur?, Journal of Labor Economics, 16, 26-60.

Boeri, T. and Cramer, U. (1992), Employment Growth, Incumbents and Entrants: Evidence from Germany, International Journal of Industrial Organization, 10, 545-66.

Bottazzi, G. and Secchi, A. (2006), Gibrat's Law and Diversification, Industrial and Corporate Change, 15, 847-75.

Braunerhjelm, P. (2011), Entrepreneurship, Innovation and Economic Growth: Interdependencies, Irregularities and Regularities, in Audretsch, D.B., Falck, O., Heblich, S. and Lederer, A. (Eds.), Handbook of Research on Innovation and Entrepreneurship, Cheltenham, Elgar, 161-213.

Burke A., FitzRoy, F. and Nolan, M. (2008), What Makes a Die-hard Entrepreneur? Beyond the 'Employee or Entrepreneur' Dichotomy, Small Business Economics, 31, 93-115.

Cabral, L. (1997), Entry Mistakes, Centre for Economic Policy Research, Discussion Paper No. 1729, London, CEPR.

Cabral, L. and Mata, J. (2003), On the Evolution of the Firm Size Distribution: Facts and Theory, American Economic Review, 93, 1075-90.

Calvo, J.L. (2006), Testing Gibrat's Law for Small, Young and Innovating Firms, Small Business Economics, 26, 117-23.

Camerer, C. and Lovallo, D. (1999), Overconfidence and Excess Entry: An Experimental Approach, American Economic Review, 89, 306-18.

Canales, R and Nanda, R. (2008), Harvard Business School Working Papers n. 08-101, Cambridge (Mass.), Harvard Business School.

Carlsson B. Acs, Z.J., Audretsch D.B., Braunerhjelm, P. (2009), Knowledge Creation, Entrepreneurship, and Economic Growth: A Historical Review, Industrial and Corporate Change, 18, 1193-1229.

Carpenter, R.E. and Petersen, B.C. (2002), Is the Growth of Small Firms Constrained by Internal Finance?, Review of Economics and Statistics, 84, 298-309.

Carrasco, R. (1999), Transitions to and from Self-employment in Spain, Oxford Bulletin of Economics and Statistics, 61, 315-41 
Carree, M. and Thurik, A.R., (2006), Understanding the Role of Entrepreneurship for Economic Growth, in Carree, M. and Thurik, A.R. (Eds.), The Handbook of Entrepreneurship and Economic Growth, Cheltenham, Elgar, ix-xix

Carree, M., Van Stel, A., Thurik, A.R. and Wennekers, S. (2007), The Relationship between Economic Development and Business Ownership Revisited, Entrepreneurship and Regional Development, 19, 281-91.

Caves, R.E. (1998), Industrial Organization and New Findings on the Turnover and Mobility of Firms, Journal of Economic Literature, 36, 1947-82.

Cefis, E. and Marsili, O. (2005), A Matter of Life and Death: Innovation and Firm Survival, Industrial and Corporate Change, 14, 1167-92.

Cefis, E. and Marsili, O. (2006), Survivor: The Role of Innovation in Firm's Survival, Research Policy, 35, 626-41.

Coad, A. and Rao, R. (2008), Innovation and Firm Growth in High-tech Sectors: A Quantile Regression Approach, Research Policy, 37, 633-48.

Coelho, M.P., de Meza, D. and Reyniers, D. (2004), Irrational Exuberance, Entrepreneurial Finance and Public Policy, International Tax and Public Finance, 11, 391-417.

Cole, S. (2009), Fixing Market Failures or Fixing Elections? Agricultural Credit in India, American Economic Journal: Applied Economics, 1, 219-50.

Colombo, M.G., Delmastro M. and Grilli, L. (2004), Entrepreneurs' Human Capital and the Startup Size of New Technology-based Firms, International Journal of Industrial Organization, 22, 1183-211.

Colombo, M.G. and Grilli, L. (2005), Founders' Human Capital and the Growth of New Technology-Based Firms: A Competence-Based View, Research Policy, 34, 795-816.

Colombo, M.G. and Grilli, L. (2010), On Growth Drivers of High-tech Start-ups: Exploring the Role of Founders'Human Capital and Venture Capital, Journal of Business Venturing, 25, 610-26.

Cooper, A.C. (1985), The Role of Incubator Organizations in the Founding of Growth-oriented Firms, Journal of Business Venturing, 1, 75-86.

Cooper, A.C., Gimeno-Gascon, F.J. and Woo, C.Y. (1994), Initial Human Capital and Financial Capital as Predictors of New Venture Performance, Journal of Business Venturing, 9, 371-96.

Creedy, J. and Johnson, P.S. (1983), Firm Formation in Manufacturing Industry, Applied Economics, 15, 177-85.

Cressy, R. (1996), Are Business Start-ups Debt-rationed?, Economic Journal, 106, 1253-70.

Cressy, R. (2000), Credit Rationing or Entrepreneurial Risk Aversion? An Alternative Explanations for the Evans and Jovanovic Finding, Economics Letters, 66, 235-40.

Cressy, R. (2006), Why Do Most Firms Die Young?, Small Business Economics, 26, 103-16.

Dahl M. S. and Sorenson O. (2011), Home Sweet Home: Entrepreneurs' Location Choices and the Performance of Their Ventures, Management Science, forthcoming.

Das, S. (1995), Size, Age and Firm Growth in an Infant Industry: The Computer Hardware Industry in India, International Journal of Industrial Organization, 13, 111-126.

De Meza, D. (2002), Overlending?, Economic Journal, 112, F17-F31.

Djankov, S., La Porta, R., Lopez-de-Silanes, F. and Shleifer, A. (2002), The Regulation of Entry. Quarterly Journal of Economics, 117, 1-37. 
Doms, M. , Lewis, E. and Robb, A. (2010), Local Labor Force education, New Business Characteristics, and firm Performance, Journal of Urban Economics, 67, 61-77.

Dosi, G. (1988), Sources, Procedures and Microeconomic Effects of Innovation, Journal of Economic Literature, 26, 1120-71.

Dosi, G. and Lovallo, D. (1998), Rational Entrepreneurs or Optimistic Martyrs? Some Considerations on Technological Regimes, Corporate Entries, and the Evolutionary Role of Decision Biases, in Garud, R., Nayyar, P. and Shapiro, Z. (eds.), Foresights and Oversights in Technological Change, Cambridge, Cambridge University Press, 41-68.

Dosi, G., Marsili, O., Orsenigo, L. and Salvatore, R. (1995), Learning, Market Selection and the Evolution of Industrial Structures, Small Business Economics, 7, 411-36.

Dunne, P. and Hughes, A. (1994), Age, Size, Growth and Survival: UK Companies in the 1980s, Journal of Industrial Economics, 42, 115-40.

Dunne, T., Roberts, M.J. and Samuelson, L. (1988), Patterns of Firm Entry and Exit in U.S. Manufacturing Industries, Rand Journal of Economics, 19, 495-515.

Dunne, T., Roberts, M.J. and Samuelson, L. (1989), The Growth and Failure of US Manufacturing Plants, Quarterly Journal of Economics, 104, 671-98.

Elkan, W (1988), Entrepreneurs and Entrepreneurship in Africa, World Bank Research Observer, 3, 171-88.

Ericson, R. and Pakes, A. (1995), Markov-Perfect Industry Dynamics: a Framework for Empirical Work, Review of Economic Studies, 62, 53-82.

Esteve-Pérez S., Sanchis A. and Sanchis J. A. (2004), The Determinants of Survival of Spanish Manufacturing Firms, Review of Industrial Organization, 25, 251-73.

Evans, D.S. (1987), The Relationship Between Firm Growth, Size, and Age: Estimates for 100 Manufacturing Industries, Journal of Industrial Economics, 35, 567-81.

Evans, D.S. and Jovanovic, B. (1989), An Estimated Model of Entrepreneurial Choice under Liquidity Constraints, Journal of Political Economy, 97, 808-27.

Evans, D.S. and Leighton L.S. (1989), Some Empirical Aspects of Entrepreneurship, American Economic Review, 79, 519-35.

Evans, L.B. and Leighton L.S. (1990), Small Business Formation by Unemployed and Employed Workers, Small Business Economics, 2, 319-30.

Fairlie, R. and Robb, A. (2008), Why Are Black-owned Businesses Less Successful than Whiteowned Businesses? The Role of Families, Inheritances, and Business Human Capital, Journal of Labor Economics, 25, 289-323.

Fazzari, S.M., Hubbard, R.G. and Petersen, B.C. (1988), Financing Constraints and Corporate Investment, Brookings Papers on Economic Activity, 115, 695-713.

Fisman, R. and Svensson, J. (2007), Are Corruption and Taxation Really Harmful to Growth? Firm Level Evidence, Journal of Development Economics, 83, 63-75.

Fogel, K., Lee, K. and McCumber, W. (2011), Institutional Impact on the Outreach and Profitability of Microfinance Organizations, in Audretsch, D.B., Falck, O., Heblich, S. and Lederer, A. (Eds.), Handbook of Research on Innovation and Entrepreneurship, Cheltenham, Elgar, 119-33.

Foster L., Haltiwanger, J. and Syverson, C. (2008), Reallocation, Firm Turnover, and Efficiency: Selection on Productivity or Profitability?, American Economic Review, 98, 394-425, 
Foti, A. and Vivarelli, M. (1994), An Econometric Test of the Self-employment Model: The case of Italy, Small Business Economics, 6, 81-93.

Freel, M.S. (2000), Do Small Innovating Firms Outperform Non-innovators?, Small Business Economics, 14, 195-210.

Frenken, K., Cefis, E. and Stam, E. (2011), Industrial Dynamics and Economic Geography: A Survey, Ecis Working Paper no. 11.07, Eindhoven Centre for Innovation Studies.

Fritsch M. (2011) The Effect of New Business Formation on Regional Development - Empirical Evidence, Interpretation, and Avenues for Further Research, Jena Economic Research Papers no.2011-006, Jena, Friedrich-Schiller-University.

Fritsch M. and Mueller P. (2007), The Persistence of Regional New Business Formation Activity Over Time. Assessing the Potential of Policy Promotion Programs, Journal of Evolutionary Economics, 17, 299-315.

Geroski, P.A. (1995), What do We know about Entry?, International Journal of Industrial Organization, 13, 421-40.

Geroski, P.A. and Mazzucato, M. (2001), Modelling the Dynamics of Industry Populations, International Journal of Industrial Organization, 19, 1003-22.

Geroski, P.A. and Schwalbach J. (eds.), (1991), Entry and Market Contestability: An International Comparison, Oxford, Basil Blackwell.

Ghani, E., Kerr, W.R. and O’Connell, S.D. (2011a), Promoting Entrepreneurship, Growth and Job Creation, in Ghani, E. (ed.), Reshaping Tomorrow, Delhi, Oxford University Press, ch.7.

Ghani, E., Kerr, W.R. and O’Connell, S.D. (2011b), Spatial Determinants of Entrepreneurship in India, NBER Working Paper 17514, Cambridge (Mass.), NBER.

Ghani, E., Kerr, W.R. and O’Connell, S.D. (2011c), Who Creates Jobs?, Economic Premises, 70, 1-7.

Gibrat, R. (1931), Les Inegalites Economiques, Paris, Librairie du Recueil Sirey.

Gimeno, J, Folta, T., Cooper, A. and Woo, C. (1997), Survival of the Fittest? Entrepreneurial Human Capital and the Persistence of Underperforming Firms, Administrative Science Quarterly, 42, 750-83.

Glaeser, E., Kerr, W. and Ponzetto, G. (2010), Clusters of Entrepreneurship, Journal of Urban Economics, 67, 150-68.

Goddard, J., Wilson, J. and Blandon, P. (2002), Panel Tests of Gibrat's Law for Japanese Manufacturing, International Journal of Industrial Organization, 20, 415-33.

Goedhuys, M. and Sleuwaegen, L. (1999), Barriers to Growth of Firms in Developing Countries, Evidence from Burundi, in Audretsch, D. and Thurik, R. (eds), Innovation, Industry Evolution and Employment, Cambridge, Cambridge University Press, 297-314.

Goedhuys, M. and Sleuwaegen, L. (2000), Entrepreneurship and Growth of Entrepreneurial Firms in Côte d'Ivoire, The Journal of Development Studies, 36, 123-45.

Goedhuys, M. and Sleuwaegen, L. (2010), High-growth Entrepreneurial Firms in Africa: A Quantile Regression Approach, Small Business Economics, 34, 31-51.

Gompers, A., Kovner, A., Lerner, J. and Scharfstein, D. (2006), Skill vs. Luck in Entrepreneurship and Venture Capital: Evidence from Serial Entrepreneurs, NBER Working Paper 12592, Cambridge (Mass.), NBER. 
Greif, A. (1993), Contract Enforceability and Economic Institutions in Early Trade: The Maghribi Traders' Coalition, American Economic Review, 83, 525-48.

Grossman, G. and Helpman, E. (1991), Innovation and Growth in the World Economy, Cambridge (Mass.), MIT Press.

Guiso, L. and Schivardi, F. (2005), Learning To Be an Entrepreneur, CEPR Discussion Paper $n$. 5290, London, CEPR.

Gunning, J.W. and Mengistae, T. (2001), Determinants of African Manufacturing Investments: The Microeconomic Evidence, Journal of African Economies, 10, 48-80.

Hall, B. (1987), The Relationship Between Firm Size and Firm Growth in the US Manufacturing Sector, Journal of Industrial Economics, 35, 583-606.

Hamilton, R.T (1989), Unemployment and Business Formation Rates: Reconciling Time-series and Cross-section Evidence, Environment and Planning, 21, 249-55.

Hart, P.E. and Oulton, N. (1996), Growth and Size of Firms, Economic Journal, 106, 1242-52.

Hart, P.E. and Oulton, N. (2001), Galtonian Regression, Company Age and Job Generation 198695, Scottish Journal of Political Economy, 48, 82-98.

Helfat, C.E. and Lieberman, M.B. (2002), The Birth of Capabilities: Market Entry and the Importance of Pre History, Industrial and Corporate Change, 11, 725-60.

Hewitt, T. and Wield, D. (1997), Tanzanian Networks, Networks in Tanzanian Industrialization, Science and Public Policy, 24, 395-404.

Highfield, R. and Smiley, R. (1987), New Business Starts and Economic Activity: An Empirical Investigation, International Journal of Industrial Organization, 5, 51-66.

Hirakawa, O., Muendler, M. A. and Rauch, J. E. (2010), Employee Spinoffs and Other Entrants: Stylized Facts from Brazil, International Growth Centre Working Paper 10/0879, London, LSE.

Hobday, M. (1995), Innovation in East Asia: The Challenge to Japan, Cheltenham, Elgar.

Holtz-Eakin, D., Joulfaian, D., Rosen, H. (1994), Sticking it out: Entrepreneurial Survival and Liquidity Constraints, Journal of Political Economy, 102, 53-75.

Hopenhayn, H. (1992), Entry, Exit and Firm Dynamics in Long Run Equilibrium, Econometrica $60,1127-1150$.

Hout, M. and Rosen, H. (2000), Self-employment, Family Background and Race, Journal of Human Resources, 35, 670-692.

Hurst, E. and Lusardi, A. (2004), Liquidity Constraints, Household Wealth and Entrepreneurship, Journal of Political Economy, 112, 319-347.

Ihrig, J. and Moe, K.S. (2004), Lurking in the Shadows: The Informal Sector and Government Policy, Journal of Development Economics, 73, 541-57.

Iyer, R. and Schoar, A. (2010), Are there Cultural Determinants of Entrepreneurship?, in Lerner, J. and A. Schoar (eds.), International Differences in Entrepreneurship, Chicago, University of Chicago Press, 209-40.

Jarmin, R. and Krizan, C.J. (2010), Past Experience and Future Success: New Evidence on Owner Characteristics and Firm Performance, CES Discussion Papers 10-24, Washington, U.S. Bureau of the Census - Center for Economic Studies.

Kan, K. and Tsai, W.D. (2006), Entrepreneurship and Risk Aversion, Small Business Economics, 26, 465-74. 
Kerr, W.R. and Nanda, R. (2011), Financing Constraints and Entrepreneurship, in Audretsch, D.B., Falck, O., Heblich, S. and Lederer, A. (Eds.), Handbook of Research on Innovation and Entrepreneurship, Cheltenham, Elgar, 88-103.

Khemani, R.S. and Shapiro, D.M. (1986), The Determinants of New Plant Entry in Canada, Applied Economics, 18, 1243-57.

Kihlstrom, R.E and Laffont, J.J. (1979), A General Equilibrium Entrepreneurial Theory of Firm Formation Based on Risk Aversion, Journal of Political Economy, 87, 719-48.

Kilby, P. (1983), The Role of Alien Entrepreneurs in Economic Development, an Entrepreneurial Problem, American Economic Review, Papers and Proceedings, 73, 107-11.

Kirzner, I. (1973), Competition and Entrepreneurship, Chicago, University of Chicago Press.

Kirzner, I. (1997), Entrepreneurial Discovery and the Competitive Market Process: An Austrian Approach, Journal of Economic Literature, 35, 60-85.

Klapper, L., Laeven, L. and Rajan, R.G. (2006), Business Regulations as a Barrier to Entrepreneurship, Journal of Financial Economics, 82, 591-629.

Klapper, L. and Love, I. (2011), Entrepreneurship and Development: The Role of Information Asymmetries, World Bank Economic Review, 25, 1-8.

Klepper, S. (2001), Employee Startups in High-tech Industries, Industrial and Corporate Change, 10, 639-74.

Klepper S. (2009), Spinoffs: A Review and Synthesis, European Management Review, 6, 159-71.

Knight, F.H. (1921), Uncertainty and Profit, New York, Houghton Mifflin.

Johnson, P.S. (1983), New Manufacturing Firms in the U.K. Regions, Scottish Journal of Political Economy, 30, 75-9.

Johnson, P.S. (1986), New Firms: An Economic Perspective, London, Allen \& Unwin.

Johnson, P.S. (2005), Targeting Firm Births and Economic Regeneration in a Lagging Region, Small Business Economics, 24, 451-64.

Jovanovic, B. (1982), Selection and Evolution of Industry, Econometrica, 50, 649-70.

Lall, S. (1992), Technological Capabilities and Industrialization, World Development, 20, 165-86.

Lall, S. (2004), The Employment Impact of Globalization in Developing Countries, in Lee, E. and Vivarelli, M. (2004) (Eds), Understanding Globalization, Employment and Poverty Reduction, New York, Palgrave Macmillan, 73-101.

Lazear, E. (2004), Balanced Skills and Entrepreneurship, American Economic Review Papers and Proceedings, 94, 208-11.

Lazear, E. (2005), Entrepreneurship, Journal of Labor Economics, 23, 649-80

Lee, D. and Tsang, E. (2001), The Effects of Entrepreneurial Personality, Background and Network Activity on Venture Growth, Journal of Management Studies, 38, 583-602.

Lee, E. and Vivarelli, M. (2006), The Social Impact of Globalization in Developing Countries. International Labour Review, 145, 167-184.

Lee, S-H., Yamakawa, Y., Peng, M.W. and Barney, J.B. (2011), How Do Bankruptcy Laws Affect Entrepreneurship Development Around the World?, Journal of Business Venturing, 26, 505-20.

Lévesque, M. and Shepherd, D. A. (2004), Entrepreneurs' Choice of Entry Strategy in Emerging and Developed Markets, Journal of Business Venturing, 19, 29-54. 
Lindh, T. and Ohlsson, D.N. (1996), Self-employment and Windfall Gains: Evidence from the Swedish Lottery, Economic Journal, 106, 1515-26.

Lotti, F. and Santarelli, E. (2004), Industry Dynamics and the Distribution of Firm Sizes: A Nonparametric Approach, Southern Economic Journal, 70, 443-66.

Lotti, F., Santarelli, E. and Vivarelli, M. (2003), Does Gibrat's Law Hold Among Young, Small Firms?, Journal of Evolutionary Economics, 13, 213-35.

Lotti, F., Santarelli, E. and Vivarelli, M. (2009), Defending Gibrat's Law as a Long-Run Regularity, Small Business Economics, 32, 31-44.

Lucas, R.E., Jr. (1978), On the Size Distribution of Business Firms, Bell Journal of Economics, 9, 508-23.

Lucas, R.E., Jr. (1988), On the Mechanics of Economic Development, Journal of Monetary Economics, 22, 3-42.

Maloney, W. (2004), Informality Revisited, World Development, 32, 1159-78.

Mansfield, E. (1962), Entry, Gibrat's Law, Innovation and the Growth of Firms, American Economic Review, 52, 1023-51.

Masuda, T. (2006), The Determinants of Latent Entrepreneurship in Japan, Small Business Economics, 26, 227-40.

Mata, J., Portugal, P. and Guimaraes, P. (1995), The Survival of New Plants: Start-up Conditions and Post-entry Evolution, International Journal of Industrial Organization, 13, 459-82.

McPherson, M.A. (1996), Growth of Micro and small enterprises in Southern Africa, Journal of Development Economics, 48, 253-77.

Mead, D.C. and Liedholm, C. (1998), The Dynamics of Micro and Small Enterprises in Developing Countries, World Development, 26, 61-74.

Mengistae, T. (2001), Indigenous Ethnicity and Entrepreneurial Success in Africa: Some Evidence from Ethiopia, World Bank Policy Research Working Paper 2534, Washington DC, World Bank.

Michelacci, C. and Silva, O. (2007), Why so Many Local Entrepreneurs?, Review of Economics and Statistics, 89, 615-33.

Nafziger, E.W. and Terrell, D. (1996), Entrepreneurial Human Capital and the Long-Run Survival of Firms in India, World Development, 24, 689-96.

Naudé, W.A. (2009), Out With the Sleaze, in With the Ease: Insufficient for Entrepreneurial Development?, UNU-WIDER Research Paper no. 2009/01, United Nations University, Helsinki.

Naudé, W. (2010), Entrepreneurship, Developing Countries, and Development Economics: New Approaches and Insights, Small Business Economics, 34, 1-12.

Nugent, J.B. and Nabli, M.K.(1992), Development of Financial Markets and the Size Distribution of Manufacturing Establishments: International Comparisons, World Development, 20, 1489-99.

Nyström, K. (2008), Is Entrepreneurship the Salvation for Enhanced Economic Growth?, CESIS Electronic Working Paper Series no. 143, Royal Institute of Technology, Sweden.

OECD (2003), The Sources of Economic Growth in OECD Countries, Paris, OECD.

Orr, D. (1974), The Determinants of Entry: A Study of the Canadian Manufacturing Industries, Review of Economics and Statistics, 56, 58-66. 
Oxenfeldt, A.R. (1943), New Firms and Free Enterprise: Pre-War and Post-War Aspects, Washington, American Council on Public Affairs.

Pakes, A. and Ericson, R. (1998), Empirical Implications of Alternative Models of Firm Dynamics, Journal of Economic Theory, 79, 1-45.

Paravisini, D. (2008), Local Bank Financial Constraints and Firm Access to External Finance, Journal of Finance, 63, 2161-93.

Parker, S.C. (1997), The Effects of Risk on Self-employment, Small Business Economics, 9, 51522.

Parker, S.C. (2000), Saving to Overcome Borrowing Constraints: Implications for Small Business Entry and Exit, Small Business Economics, 15, 223-32.

Parker, S.C. (2004), The Economics of Self-Employment and Entrepreneurship, Cambridge, Cambridge University Press.

Parker, S.C. (2006), New Agendas in the Economics of Entrepreneurship: Optimism, Education, Wealth and Entrepreneurship, paper presented at the $3^{\text {rd }}$ HE.W.P.E.M. (Hellenic Workshop on Efficiency and Productivity Measurement): "Industry Dynamics, Productivity, Entrepreneurship and Growth”, University of Patras, June 16-18.

Pavitt K. (1984), Sectoral Patterns of Technical Change: Towards a Taxonomy and a Theory, Research Policy, 13, 343-73.

Pfeiffer, F. and Reize, F. (2000), Business Start-ups by the Unemployed - An Econometric Analysis Based on Firm Data, Labour Economics, 7, 629-63.

Rajan, R.G. and Zingales, L. (1998), Financial Dependence and Growth, American Economic Review, 88, 559-86.

Ramachandran, V. and Shah, M.K. (1999), Minority Entrepreneurs and Firm Performance in SubSaharan Africa, Journal of Development Studies, 36, 71-87.

Raspe,O. and Van Oort, F. G. (2008), Firm Growth and Localized Knowledge Externalities, Journal of Regional Analysis and Policy, 38, 100-16.

Reid, G.C. (1991), Staying in Business, International Journal of Industrial Organization, 9, 54556.

Reynolds, P.D. (1997), Who Starts New Firms? - Preliminary Explorations of Firms-in-Gestation, Small Business Economics, 9, 449-62.

Reynolds, P.D., Bosma, E., Autio, E., Hunt, S., De Bono, N., Servais, I., Lopez-Garcia, P., Chin, N. (2005), Globa Entrepreneurship Monitor: Data Collecting Design and Implementation 19982003, Small Business Economics, 24, 205-31.

Reynolds, P.D., Camp, M. S., Bygrave, W.D., Autio, E. and Hay, M. (2001), Global Entrepreneurship Monitor. 2001 Summary Report, London, London Business School and Babson College.

Robbins, D. (2003), The Impact of Trade Liberalization upon Inequality in Developing Countries A review of Theory and Evidence. ILO Working Paper, n.13, Geneva, International Labour Organization.

Robbins, D. and Gindling, T.H. (1999), Trade Liberalization and the Relative Wages for MoreSkilled Workers in Costa Rica. Review of Development Economics, 3, 140-154.

Romer, P.M. (1986), Increasing Returns and Long-Run Growth, Journal of Political Economy, 98, S71-S102. 
Romer, P.M. (1990), Endogenous Technical Change, Journal of Political Economy, 94, 1002-37.

Santarelli, E. (2006), Introduction, in E. Santarelli (ed.), Entrepreneurship, Growth, and Innovation: The Dynamics of Firms and Industries, New York, Springer, xiii-xx.

Santarelli, E., Carree, M. and Verheul, I. (2009), Unemployment and Firm Entry and Exit: An Update on a Controversial Relationship, Regional Studies, 43, 1061-73.

Santarelli, E. and Tran, H. T. (2011), Growth of Incumbent Firms and Entrepreneurship in Vietnam, Working Papers DSE n. 785, Bologna, Dipartimento Scienze Economiche - Universita' di Bologna.

Santarelli, E. and Vivarelli, M. (2002), Is Subsidizing Entry an Optimal Policy?, Industrial and Corporate Change, 11, 39-52.

Santarelli, E. and Vivarelli, M. (2007), Entrepreneurship and the Process of Firms' Entry, Survival and Growth, Industrial and Corporate Change, 16, 455-88.

Schumpeter, J.A. (1934), The Theory of Economic Development, Cambridge (Mass.), Harvard University Press.

Schumpeter, J.A. (1939), Business Cycles: A Theoretical, Historical and Statistical Analysis of the Capitalist Process, New York, McGraw-Hill.

Schumpeter, J.A. (1943), Capitalism, Socialism and Democracy, New York, Harper.

Shane, S. (1997), Who Is Publishing the Entrepreneurship Research? Journal of Management, 23, 83-95.

Shane, S. (2000), Prior Knowledge and the Discovery of Entrepreneurial Opportunities, Organization Science, 11, 448-69.

Shane, S. (2001), Technological Opportunities and New Firm Creation, Management Science, 47, 205-20.

Silva, O. (2007), The Jack-of-All-Trades Entrepreneur: Innate Talent or Acquired Skill?, Economics Letters, 97, 118-23

Sleuwaegen, L. and Goedhuys, M. (2002), Growth of Firms in Developing Countries, Evidence from Côte d'Ivoire, Journal of Development Economics, 68, 117-35.

Small Business Service (2001), Global Entrepreneurship Monitor. 2001 UK Executive Report, London, London Business School.

Stam E. (2007), Why Butterflies Don't Leave. Locational Behavior of Entrepreneurial Firms, Economic Geography, 83, 27-50.

Storey, D.J. (1982), Entrepreneurship and the New Firm, London, Croom Helm.

Storey, D.J. (1991), The Birth of New Firms - Does Unemployment Matter? A Review of the Evidence, Small Business Economics, 3, 167-78.

Storey, D. J. (1994), Understanding the Small Business Sector, London, Routledge.

Storey, D.J. and Johnson, S. (1987), Regional Variations in Entrepreneurship in the U.K., Scottish Journal of Political Economy, 34, 161-73.

Storey, D.J. and. Jones, A.M (1987), New Firm Formation - A Labor Market Approach to Industrial Entry, Scottish Journal of Political Economy, 34, 37-51.

Sutton, J. (1991), Sunk Costs and Market Structure, Cambridge (Mass.), MIT Press.

Sutton, J. (1997), Gibrat’s Legacy, Journal of Economic Literature, 35, 40-59. 
Teixeira, A. (2011), Mapping the (In)visible College(s) in the Field of Entrepreneurship, Scientometrics, 89, 1-36.

Thurik, A.R. (2003), Entrepreneurship and Unemployment in the UK, Scottish Journal of Political Economy, 50, 264-90.

Tybout, J.R. (2000), Manufacturing Firms in Developing Countries: How Well Do They Do and Why?, Journal of Economic Literature, 38, 11-44.

Van de Sluis, J., Van Praag, M. and Vijverberg, W. (2004), Entrepreneurship Selection and Performance: A Meta-analysis of the Impact of Education in Less Developed Countries, Tinbergen discussion paper TI 03-036/3. Rotterdam: Tinbergen Institute.

Van Praag, M.C. and Versloot, P.H. (2007), What Is the Value of Entrepreneurship?, A Review of Recent Research, Small Business Economics,29, 351-82.

Van Stel, A.J., Carree, M. and Thurik, A.R. (2005), The Effect of Entrepreneurial Activity on National Economic Growth, Small Business Economics, 24, 311-21.

Vijverberg, W. (1991), Profits from Self-Employment: The Case of Côte d'Ivoire, World Development, 19, 683-96.

Vivarelli, M. (1991), The Birth of New Enterprises, Small Business Economics, 3, 215-23.

Vivarelli, M. (2004), Are All the Potential Entrepreneurs So Good?, Small Business Economics, 23, 41-9.

Vivarelli, M. (2007), Entry and Post-Entry Performance of Newborn Firms, London, Routledge.

Vivarelli, M. and Audretsch, D.B. (1998), The Link between the Entry Decision and Post-entry Performance: Evidence from Italy, Industrial and Corporate Change, 7, 485-500.

Wagner, J. (2003), Testing Lazear's Jack-of-all-trades View of Entrepreneurship with German Microdata, Applied Economics Letters, 10, 687-89.

Wang, S. (2006), Determinants of New Firm Formation in Taiwan, Small Business Economics, 27, 313-23.

Wennekers, S., van Stel, A.J., Thurik, A.R. and Reynolds, P.D. (2005), Nascent Entrepreneurship and the Level of Economic Development, Small Business Economics, 24, 293-309.

Winter, S.G. (1991), On Coase, Competence, and the Corporation, in Williamson, O.E. and Winter, S.G. (eds.), The Nature of the Firm: Origins, Evolution and Development, Oxford, Oxford University Press, 179-95.

Xu, B. (1998), A Reestimation of the Evans-Jovanovic Entrepreneurial Choice Model, Economics Letters, 58, 91-5.

Yasuda, T. (2005), Firm Growth, Size, Age, and Behavior in Japanese Manufacturing, Small Business Economics, 24, 1-15.

Yunus, M. (1999), Banker to the Poor, London, Aurum Press.

Yunus, M. (2002), Toward Eliminating Poverty from the World: Grameen Bank Experience, in Anderson, L.C. and J.W. Looney (eds.), Making Progress Essays in Progress and Public Policy, Lanham and Oxford, Lexington Books, 371-8.

Zacharakis, A.L., Bygrave, W.D. and Shepherd, D.A. (2000), Global Entrepreneurship Monitor. National Entrepreneurship Assessment: United States of America, 2000 Executive Report, Babson Park (Mass), Babson College. 